\title{
PERCUTANEOUS FIXATION OF FRACTURES OF THE SPINE: 1-YEAR CLINICAL AND RADIOLOGICAL FOLLOW-UP
}

\author{
FIXAÇÃO PERCUTÂNEA DE FRATURAS DA COLUNA VERTEBRAL: SEGUIMENTO CLÍNICO \\ E RADIOLÓGICO DE 1 ANO
}

\author{
FIJACIÓN PERCUTÁNEA DE LAS FRACTURAS VERTEBRALES: SEGUIMIENTO CLÍNICO \\ Y RADIOLÓGICO DE 1 AÑO
}

Carlos Fernando Pereira da Silva Herrero' ${ }^{1}$ Anderson luís do Nascimento', Mario Bressan Neto', Diego Polizello',

Marcelo Henrique Nogueira-Barbosa' ${ }^{1}$, Helton Luiz Aparecido Defino ${ }^{1}$

\begin{abstract}
Objective: To evaluate the preliminary results of the surgical treatment through minimally invasive fixation technique in patients with thoracolumbar spinal fractures. Methods: Retrospective study of 17 patients with fractures of thoracolumbar vertebrae who underwent surgery with percutaneous fixation in the period of 2009 to 2011. The clinical evaluation of the results was performed using the SF-36 and Oswestry questionnaires. The radiographic parameters evaluated were: fracture classification according to Magerl's criteria, wedge angle of the fractured vertebrae and bisegmental Cobb angle. These measurements were made in the preoperative, immediate postoperative and 1 year after surgery. Other data such as associated injuries, neurological deficit, post-surgical infection, loosening and breakage of implants were also considered. Results: The data revealed average scores above $80 \%$ in all domains of the SF-36 questionnaire while in Oswestry Questionnaire, $79 \%$ of patients had minimal or absent physical limitations with a mean score of $12.4 \pm 11.89 \%$. The average Cobb angle for preoperative kyphosis was $5.53^{\circ} \pm 13.80^{\circ}, 2.18^{\circ} \pm 13.38^{\circ}$ in the early postoperative period and $5.26^{\circ} \pm 13.95^{\circ}$ one year after surgery. The average correction obtained after surgery was $3.35^{\circ}$ and the average correction loss was $3.19^{\circ}$. No complications such as post-surgical infection, permanent neurological deficits and implant loosening and breakage were observed. Conclusion: The surgical treatment of fractures of thoracolumbar vertebrae using a minimally invasive technique provides satisfactory clinical and radiographic results with low complication rates.
\end{abstract}

Keywords: Spine; Spinal injuries; Spinal fractures; Fracture fixation.

\section{RESUMO}

Objetivo: Avaliar os resultados preliminares do tratamento cirúrgico pela técnica de fixação minimamente invasiva em pacientes portadores de fraturas toracolombares da coluna vertebral. Métodos: Estudo retrospectivo de 17 pacientes com fraturas de vértebras toracolombares submetidos a tratamento cirúrgico com fixação percutânea no período de 2009 a 2011. A avaliação clínica dos resultados foi realizada através dos questionários SF-36 e Oswestry. Os parâmetros radiográficos avaliados foram: classificação das fraturas segundo critérios de Magerl, ângulo de acunhamento da vértebra fraturada e o ângulo de Cobb bissegmentar do segmento afetado. Estas medidas foram feitas nos períodos pré-operatório, pós-operatório imediato e 1 ano após a cirurgia. Outros dados como lesões associadas, déficit neurológico, infecção pós-cirúrgica, soltura e quebra de implantes também foram considerados. Resultados: Os dados obtidos revelaram médias acima de $80 \%$ em todos os domínios do Questionário SF-36 enquanto que no Questionário de Oswestry, 79\% dos indivíduos apresentaram limitações físicas mínimas ou

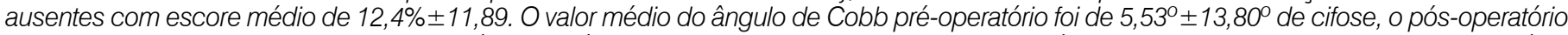

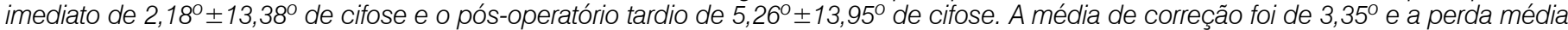
de correção, de 3,19\%. Não foram obsenvadas complicações como infecção pós-cirúrgica, déficit neurológico permanente, soltura ou quebra de implantes. Conclusão: O tratamento cirúrgico das fraturas de vértebras toracolombares com a utilização de técnica minimamente invasiva proporciona resultados clínicos e radiográficos satisfatórios, com baixos índices de complicações.

Descritores: Coluna vertebral; Traumatismos da coluna vertebral; Fraturas da coluna vertebral, Fixação de fratura.

\section{RESUMEN}

Objetivo: Evaluar los resultados preliminares de la técnica de tratamiento quirúrgico para la fijación mínimamente invasiva en pacientes con fracturas de la columna toracolumbar. Métodos: Estudio retrospectivo de 17 pacientes con fracturas de vértebras toracolumbares fueron sometidos a cirugía con fijación percutánea en el período de 2009 a 2011. Se realizó la evaluación clínica de los resultados utilizando los cuestionarios SF-36 y Oswestry. Se evaluaron los parámetros radiográficos: clasificación de fracturas según criterios de Magerl, ángulo de acuñamiento de la vértebra fracturada y el ángulo de Cobb bissegmentar del segmento afectado. Estas mediciones se realizaron en el preoperatorio, postoperatorio inmediato y 1 año después de la cirugía. También se consideraron otros datos, tales como lesiones asociadas, déficit neurológico, infección post-quirúrgica y aflojamiento y rotura de los implantes. Resultados: Los datos indican promedios superiores al 80\% en todos los dominios del cuestionario SF-36, mientras que en cuestionario Oswestry, el 79\% de los pacientes tenían limitaciones físicas mínimas o ausentes con una puntuación media de 12,4 $\pm 11,89 \%$. El ángulo de Cobb preoperatorio promedio fue $5,53^{\circ} \pm 13,80^{\circ}$ de cifosis, el postoperatorio inmediato $2,18^{\circ} \pm 13,38^{\circ}$ de cifosis y el postoperatorio tardío 5,26 $\pm 13,95$ de cifosis. La corrección media fue de 3,35 y la pérdida media de corrección fue de $3,1^{\circ}$. No se observaron complicaciones postoperatorias tales como infección postoperatoria, déficit neurológico permanente o aflojamiento y rotura de los implantes. Conclusión: El tratamiento quirúrgico de las fracturas de vértebras toracolombares utilizando una técnica mínimamente invasiva ofrece resultados clínicos y radiográficos satisfactorios con bajas tasas de complicaciones.

Descriptores: Columna vertebral; Traumatismos vertebrales; Fracturas de la columna vertebral; Fijación de Fractura.

1. Department of Biomechanics, Medicine, and Rehabilitation of the Locomotor Apparatus of Hospital das Clínicas de Ribeirão Preto, Universidade de São Paulo, Ribeirão Preto, SP, Brazil.

Study conducted at the Spine Surgery Discipline of the Hospital das Clínicas de Ribeirão Preto da Universidade de São Paulo, Ribeirão Preto, SP, Brazil.

Correspondence: Av. dos Bandeirantes, 3900, 11 ${ }^{\circ}$ andar, Ribeirão Preto, SP, Brasil. 14048-900. fernando_herrero@ hotmail.com 


\section{INTRODUCTION}

Surgical treatment of thoracolumbar fractures of the spine is usually necessary when there is impaired biomechanical stability, or existing or imminent neurological deficit, compression of the vertebral canal, or associated injuries that prevent conservative treatment. ${ }^{1}$ However, there is still controversy surrounding the instability criteria, the need for an anterior approach in injuries with fragmentation of the vertebral body, and arthrodesis following posterior fixation. ${ }^{2,3}$

Current treatment options include conservative treatment with or without the use of ortheses, ${ }^{4}$ conventional open approaches with the use of instrumentation and arthrodesis, ${ }^{5}$ and more recently, minimally invasive posterior fixation techniques, ${ }^{6-10}$ kyphoplasty, and vertebroplasty. ${ }^{11}$ However, there is insufficient evidence in the literature to determine which of the different treatment methods is the best. ${ }^{2}$

Conservative treatment of thoracolumbar spine fractures requires prolonged restriction of activities, which often means absence from work and even bed rest, with its inherent complications. Other challenges are difficulty in controlling resulting deformities, and lack of patient understanding and cooperation. 5,12

Conventional surgical techniques using internal fixation and arthrodesis may be associated with significant morbidity, such as denervation of the paraspinal muscles, increased intramuscular pressure, muscle ischemia, pain, loss of function, blood loss, and an increased rate of infection. ${ }^{2,7,13-16}$ One surgical treatment option, minimally invasive fixation, has been used for spine fractures, and the initial results have yielded lower complication rates. ${ }^{6,7,9}$

The objective of this study was to evaluate the preliminary outcomes of surgical treatment using a minimally invasive fixation technique in patients with thoracolumbar spine fractures.

\section{MATERIALS AND METHODS}

We conducted a retrospective study of patients diagnosed with thoracolumbar spinal fractures who underwent spine surgery using a minimally invasive technique during the period from 2009 to 2011 and who are included in a prospective database. Patients diagnosed with pathological fractures, osteometabolic diseases, and infections were excluded from the study.

All the patients were operated on by the same team, with fixation surgery indicated by the Head Professor of the Spine Surgery Discipline. The implants used were the Sextant ${ }^{\circledR}$ system (Medtronic Sofamor Danek USA, Inc.,Memphis, TN, USA) following the technique described for the implant or Basis ${ }^{\circledR}$ (Medtronic) polyaxial pedicle screws via a transfascial incision following a medial skin incision. Postoperative mobilization was permitted depending on the patient's pain, without any limitations except those related to associated injuries.

The study included clinical and radiographic criteria. The clinical parameters evaluated included age, trauma mechanism, the presence of associated injury, and the occurrence of complications such as infection or neurological deficit. The SF-36 ${ }^{1}$ and Oswestry ${ }^{18}$ questionnaires were applied between 6 months and 1 year after surgery, to assess quality of life, general health, and functional capacity.

The radiographic evaluation included classification of the fractures according to the criteria of Magerl et al, ${ }^{19}$ the measurement of the angle of the wedging of the fractured vertebra and the kyphosis of the affected segment (bisegmental Cobb angle), ${ }^{20}$ (Figure 1) as well as the occurrence of complications such as the loosening or breakage of the implants. The parameters were studied in the preoperative period, immediate postoperative period and 1 year after surgery. (Figure 2)

The data analysis was performed with the assistance of $S A S^{\circledR}$ 9.0 software, using PROC MEANS and PROC MIXED to perform an exploratory analysis of the data in order to summarize a series of values of the same nature, organizing and describing the data in two ways: by means of descriptive measurements, and in the form of charts.
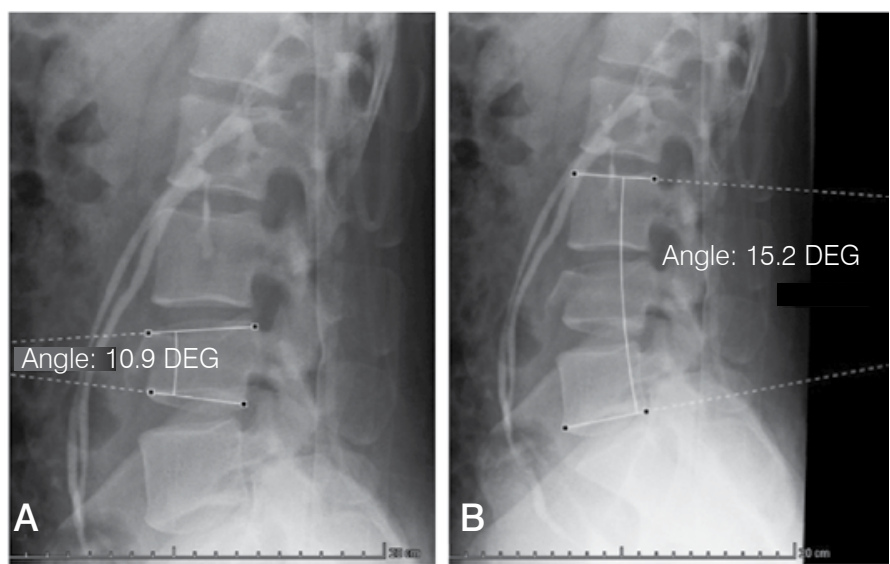

Figure 1. Measurements of the wedging angle of the vertebra $(A)$ and the bisegmental Cobb angle (B).

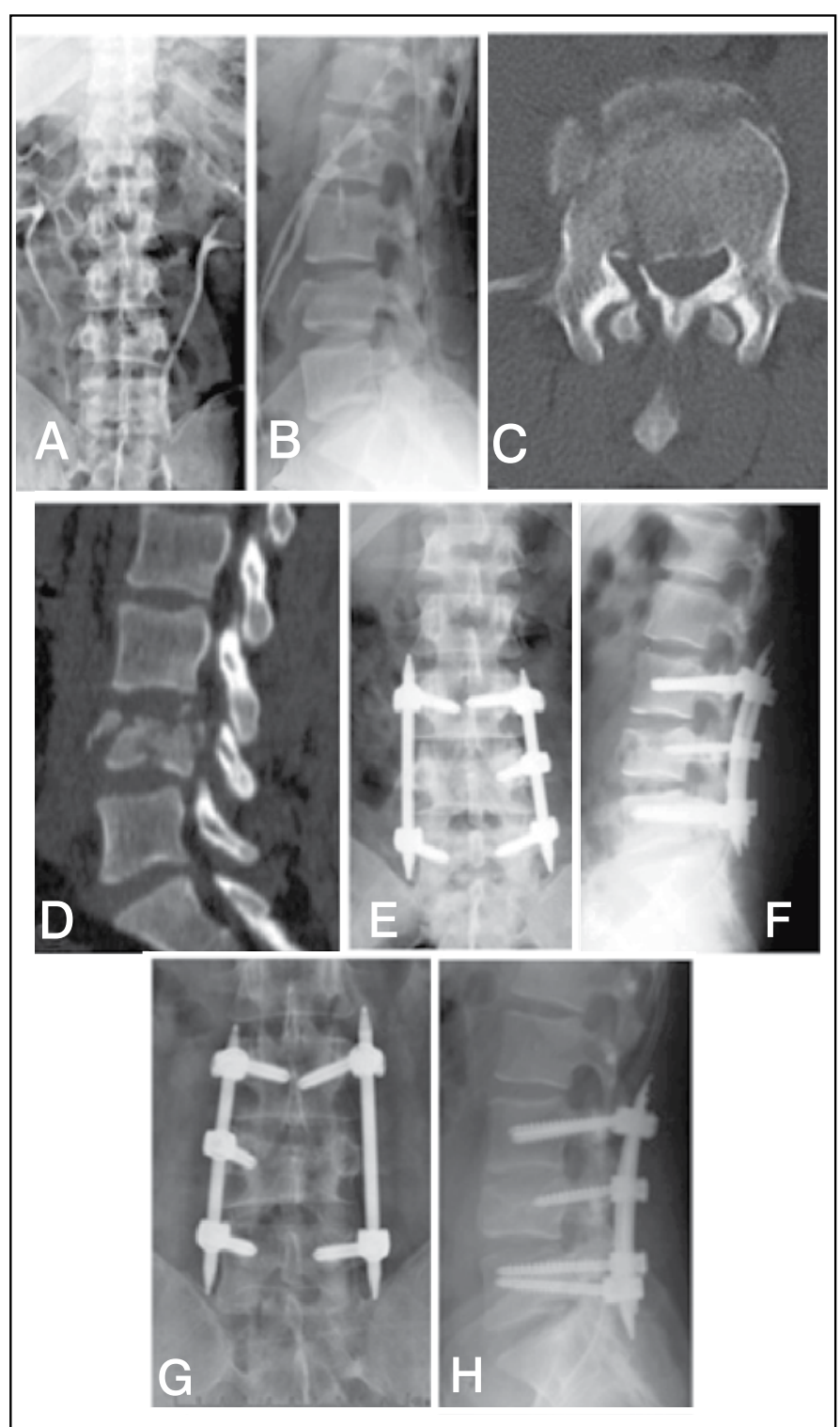

Figure 2. Twenty-one-year-old patient, victim of a traffic accident, diagnosed with a fracture of $L 4$ (Patient 13). A and B: anteroposterior and profile radiograph views showing the fracture of $L 4$. $C$ and $D$ : preoperative computed tomography. E and F: two months after fixation and stabilization with a minimally invasive technique, Sextant (Medtronic). $\mathrm{G}$ and $\mathrm{H}$ : one year after surgery. 


\section{RESULTS}

Sixteen male patients (94.12\%) and one female patient (5.88\%) aged between 16 and 60 years $(29.1 \pm 12.28)$ were included in the study. (Figure 3) Nine patients (52.95\%) underwent surgery with the Sextant ${ }^{\circledR}$ fixation system (Medtronic), and eight patients $(47.05 \%)$ underwent the minimally invasive technique with the insertion of Basis ${ }^{\circledR}$ polyaxial pedicle screws (Medtronic) via transfascial incision. Sixteen patients $(94.12 \%)$ were treated with fixation of the vertebrae one level above and one level below the fracture. In one patient $(5.88 \%)$ with a fracture of two adjacent vertebrae (T11-T12), the fixation was performed in the fractured levels (Patient 1). One patient underwent a complementary anterior approach for decompression and arthrodesis with an iliac graft (Patient 16). (Table 1)

The trauma mechanisms responsible for the fractures were automobile accidents in 11 patients (64.70\%) and falls from heights in six (35.30\%). (Figure 4) Topographically, fractures were observed in the thoracolumbar transition (T11 to L2) in 12 patients $(70.60 \%)$, with eight in L2 (47.06\%), two in L1 (11.76\%), one in T12 (5.88\%), and one patient with a fracture associated with T11 and T12 (5.88\%). The fractures occurred in the lumbar region (L3 to L5) in five patients (29.40\%): two in L3 (11.76\%), two in L4 (11.76\%), and one in L5 (5.88\%). (Figure 5) Using Magerl's criteria, ${ }^{18}$ the fractures were classified as follows: six as type A (35.29\%), five as type B (29.41\%), and six as type C (35.29\%). (Table 1)

In terms of associated injuries, nine patients (52.94\%) had other secondary injuries from the trauma: three patients $(17.64 \%)$ with fractures of the distal third of the radius, two (11.76\%) with fractured clavicles, while the other injuries were one-off occurrences, including one patient with a traumatic amputation of the lower left limb. Only one case of neurological deficit was observed during the preoperative period (Patient 16), with reduced strength at the L4 level. The patient recovered fully within the month after surgery. (Table 1) No cases of infection were observed and no reoperations were performed.

SF-36 questionnaire scores ranged from $75 \%$ to $100 \%(0.96 \pm$ $0.08)$ for social aspects and from $35 \%$ to $100 \%(0.80 \pm 0.19)$ for functional capacity. Scores ranged from 31\% to $100 \%$ for the assessment of pain $(0.80 \pm 0.20)$, from $70 \%$ to $100 \%(0.90 \pm 0.10)$ for the assessment of general health, from $25 \%$ to $100 \%(0.82 \pm$ $0.23)$ for physical limitations, from $33 \%$ to $100 \%(0.88 \pm 0.25)$ for emotional limitations, from $32 \%$ to $100 \%(0.85 \pm 0.19)$ for mental health, and from $50 \%$ to $100 \%(0.81 \pm 0.15)$ for vitality. (Figure 6 , Table 2) The evaluation of the results obtained from the Oswestry ${ }^{17}$ questionnaire yielded an average incapacitation of $12.47 \%( \pm 11.89)$ related to low back pain, with $79 \%$ of the patients reporting minimal or no incapacity. (Figures 7 and 8)

The radiographic analysis revealed spinal wedging ranging from $0^{\circ}$ to $29^{\circ}$ of kyphosis (mean of $13.06^{\circ} \pm 7.55^{\circ}$ ). The preoperative Cobb angle varied from $28^{\circ}$ of kyphosis to $22^{\circ}$ of lordosis $\left(5.53^{\circ} \pm\right.$ $13.80^{\circ}$ of kyphosis), from $27^{\circ}$ of kyphosis to $20^{\circ}$ of lordosis $\left(2.18^{\circ} \pm\right.$ $13.38^{\circ}$ of kyphosis) in the immediate postoperative period, and from $30^{\circ}$ of kyphosis to $24^{\circ}$ of lordosis $\left(5.26^{\circ} \pm 13.95^{\circ}\right.$ of kyphosis) in the late postoperative period. (Figures 9 and 10) The average correction (calculated between the preoperative and immediate postoperative periods) was $3.35^{\circ}$, the average loss of correction (calculated between the immediate postoperative period and one year after surgery) was $3.19^{\circ}$, and the average correction sustained (between the preoperative period and one year after surgery) was $0.27^{\circ}$. There was no difference between the preoperative Cobb angle measurements and those taken one year after fixation $(p=0.89)$, despite the significant correction observed in the immediate postoperative period $(p=0.0075)$. A comparison between the measurements of the immediate and late (one year after surgery) postoperative periods had statistical significance $(p=0.0123)$. (Figure 10) No signs of loosening of the material or implant failure were observed.

Regarding losses from the original sample, three patients had incomplete evaluations. In one case (Patient 11), due to the amputation of the lower limb and subsequent poor evolution of the stump,

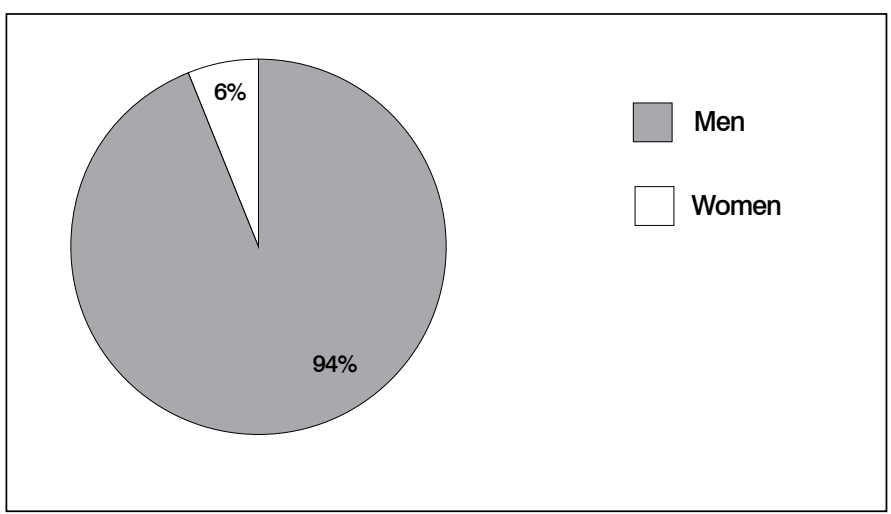

Figure 3. Distribution of patients by sex.

Table 1. Location and classification of fractures, levels fixated, and associated injuries.

\begin{tabular}{|c|c|c|c|c|}
\hline Patients & Topography & Classification & Levels fixated & Associated injuries \\
\hline Patient 1 & T11-12 & B2.1 & $\mathrm{T} 11-\mathrm{T} 12$ & - \\
\hline Patient 2 & $\mathrm{~T} 12$ & B1.1 & T11-L1 & - \\
\hline Patient 3 & $\mathrm{~L} 1$ & A3.2 & T12-L2 & \# radius \\
\hline Patient 4 & L1 & A3.3 & T12-L2 & - \\
\hline Patient 5 & L2 & B2.1 & L1-L3 & - \\
\hline Patient 6 & L2 & A3.3 & L1-L3 & $\begin{array}{c}\text { \#bilateral radius } \\
\text { and heel }\end{array}$ \\
\hline Patient 7 & L2 & C1.1 & L1-L3 & - \\
\hline Patient 8 & L2 & B1.2 & L1-L3 & \# clavicle \\
\hline Patient 9 & L2 & A2.3 & L1-L3 & \# radius \\
\hline Patient 10 & L2 & B1.1 & L1-L3 & - \\
\hline Patient 11 & L2 & C1.1 & L1-L3 & $\begin{array}{l}\text { Transfemoral } \\
\text { amputation }\end{array}$ \\
\hline Patient 12 & L2 & $\mathrm{C} 2.2$ & L1-L3 & - \\
\hline Patient 13 & L4 & C3.1 & L3-L5 & $\begin{array}{c}\text { \# metatarsals and } \\
\text { navicular }\end{array}$ \\
\hline Patient 14 & L3 & C1.1 & L2-L4 & - \\
\hline Patient 15 & L3 & A3.3 & L2-L4 & \# femur \\
\hline Patient $16^{*}$ & L4 & C1.2 & L3-L5 & \# tibia \\
\hline Patient 17 & L5 & A1.2 & L4-S1 & $\begin{array}{c}\text { \# clavicle, humerus, } \\
\text { ilium, liver trauma }\end{array}$ \\
\hline
\end{tabular}

* Patient with reduced strength at the neurological level of $L 4$, who underwent anterior approach decompression. Key: $\mathrm{L}=$ lumbar; $\mathrm{T}=$ thoracic; $\#$ = fracture

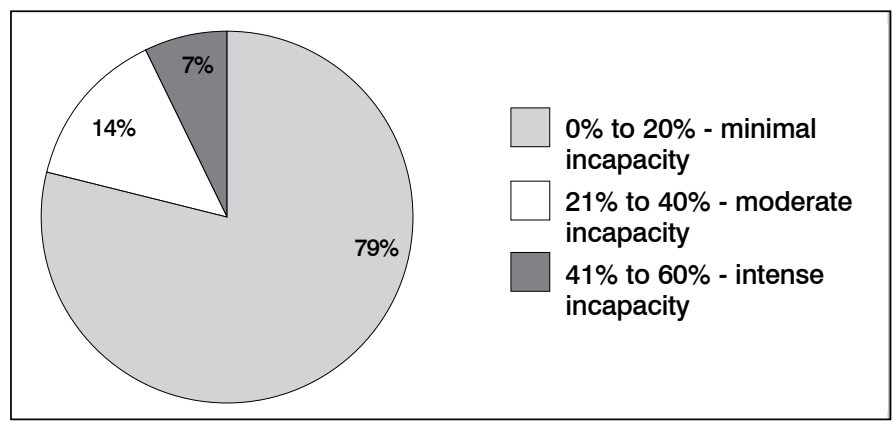

Figure 4. Distribution of trauma mechanisms involved.

functional and quality of life assessments were difficult to make and the patient was excluded from the evaluation using the questionnaires. Two other patients (Patient 8 and Patient 15) who failed to attend the stipulated return visits, were not able to be located for the interview, and therefore did not respond to the questionnaire within the determined timeframe, were also excluded from the functional evaluation. 


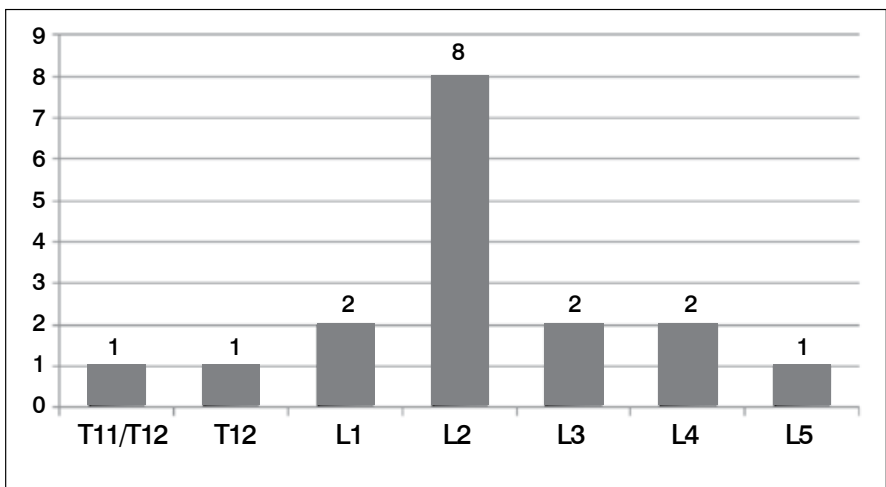

Figure 5. Topography of the fractured vertebrae.

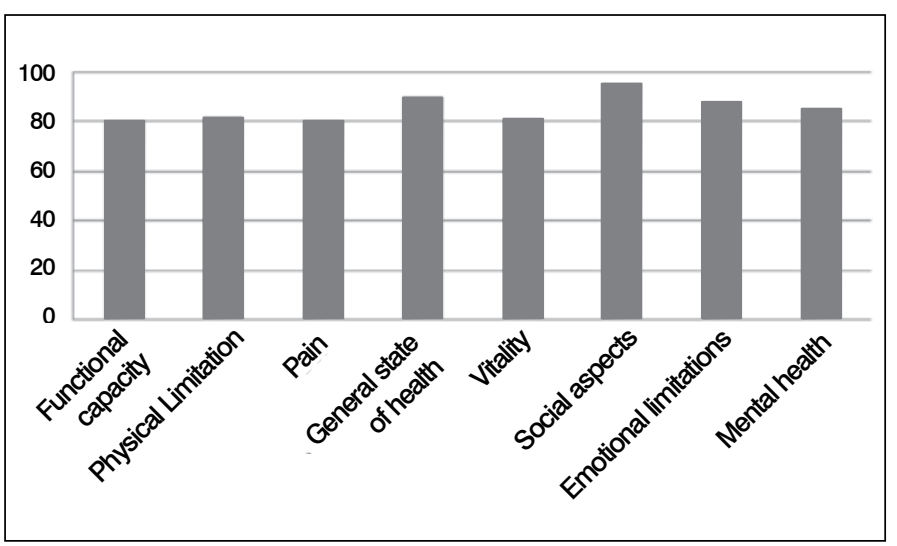

Figure 6. The average scores for the SF-36 questionnaire. ${ }^{16}$

Table 2. SF-36 scores by patient. ${ }^{16}$

\begin{tabular}{c|c|c|c|c|c|c|c|c}
\hline Patient & $\begin{array}{c}\text { Functional } \\
\text { capacity }\end{array}$ & $\begin{array}{c}\text { Physical } \\
\text { limitation }\end{array}$ & Pain & $\begin{array}{c}\text { General state } \\
\text { of health }\end{array}$ & Vitality & Social aspects & $\begin{array}{c}\text { Emotional } \\
\text { limitations }\end{array}$ & \begin{tabular}{c} 
Mental health \\
\hline 1
\end{tabular} \\
\hline $100 \%$ & $75 \%$ & $74 \%$ & $92 \%$ & $85 \%$ & $87.50 \%$ & $100 \%$ & $100 \%$ \\
\hline 2 & $90 \%$ & $100 \%$ & $80 \%$ & $100 \%$ & $70 \%$ & $100 \%$ & $100 \%$ & $88 \%$ \\
\hline 3 & $95 \%$ & $100 \%$ & $100 \%$ & $80 \%$ & $95 \%$ & $100 \%$ & $100 \%$ & $92 \%$ \\
\hline 4 & $95 \%$ & $100 \%$ & $62 \%$ & $100 \%$ & $95 \%$ & $100 \%$ & $100 \%$ & $100 \%$ \\
\hline 5 & $70 \%$ & $50 \%$ & $62 \%$ & $87 \%$ & $50 \%$ & $87.50 \%$ & $33.30 \%$ & $32 \%$ \\
\hline 6 & $90 \%$ & $100 \%$ & $80 \%$ & $97 \%$ & $90 \%$ & $100 \%$ & $100 \%$ & $96 \%$ \\
\hline 7 & $35 \%$ & $25 \%$ & $31 \%$ & $70 \%$ & $65 \%$ & $87.5 \%$ & $33.3 \%$ & $96 \%$ \\
\hline 9 & $100 \%$ & $100 \%$ & $100 \%$ & $100 \%$ & $95 \%$ & $100 \%$ & $100 \%$ & $92 \%$ \\
\hline 10 & $95 \%$ & $100 \%$ & $100 \%$ & $100 \%$ & $100 \%$ & $100 \%$ & $100 \%$ & $100 \%$ \\
\hline 12 & $70 \%$ & $75 \%$ & $74 \%$ & $92 \%$ & $85 \%$ & $100 \%$ & $100 \%$ & $92 \%$ \\
\hline 13 & $90 \%$ & $100 \%$ & $80 \%$ & $92 \%$ & $80 \%$ & $100 \%$ & $100 \%$ & $80 \%$ \\
\hline 14 & $60 \%$ & $75 \%$ & $80 \%$ & $70 \%$ & $80 \%$ & $100 \%$ & $100 \%$ & $92 \%$ \\
\hline 16 & $65 \%$ & $75 \%$ & $100 \%$ & $92 \%$ & $60 \%$ & $75 \%$ & $66,6 \%$ & $60 \%$ \\
\hline 17 & $70 \%$ & $75 \%$ & $100 \%$ & $87 \%$ & $85 \%$ & $100 \%$ & $100 \%$ & $68 \%$ \\
\hline
\end{tabular}

\section{DISCUSSION}

The minimally invasive posterior approach has been identified as an option for the treatment of thoracolumbar fractures., ${ }^{6,9}$ With its dissemination, the need to submit the patient to the limitations of conservative treatment or to the risks of conventional surgical techniques becomes questionable. ${ }^{21}$ This technique may be a good option in cases of patients with stable fractures who have constraints to conservative treatment, avoiding "overtreatment" and the additional morbidity of conventional techniques. ${ }^{8}$ Extension of the use of this technique to patients with unstable fractures may benefit those with restrictive clinical conditions requiring surgical treatment.

No surgical method has proven to be able to maintain the correction achieved by the procedure. ${ }^{2}$ The loss of correction and the

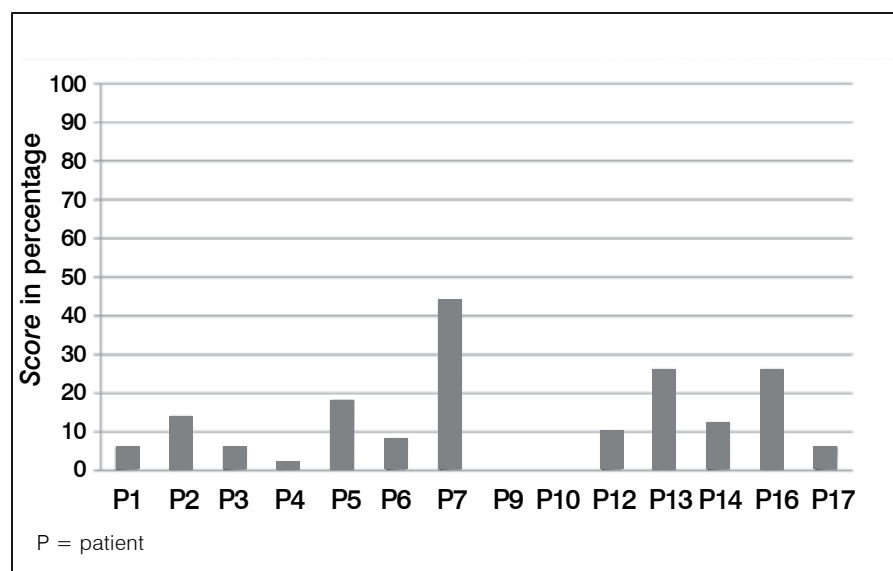

Figure 7. Percentage of incapacity based on the Oswestry questionnaire. ${ }^{17}$

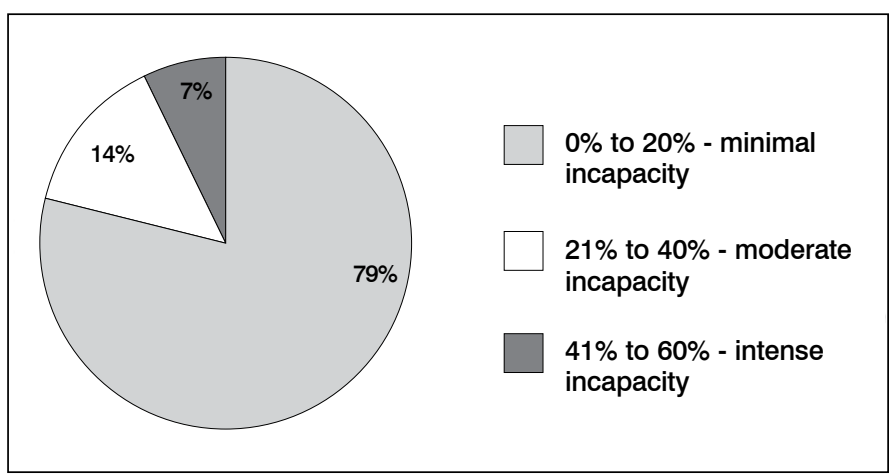

Figure 8. Distribution of patients from the interpretation of the Oswestry questionnaire. $^{17}$ wedging of the fractured vertebra are common findings during postoperative follow-up.,20-24 In our study, the surgical correction observed in the immediate postoperative period was not sustained in the long term. Like Palmisani et al, ${ }^{7}$ we believe that the structure of the polyaxial pedicle screws contributes to this loss of correction. The absence of movement in the head-body interface of the monoaxial pedicle screw could contribute to lower losses of correction, and studies to evaluate its role in minimally invasive spine surgery are necessary. We do not think that fixation without arthrodesis, achieved using a minimally invasive technique, is a decisive factor in the loss of the correction observed, because it was shown that there is no significant difference in the radiographic and clinical parameters between patients treated by means of instrumented arthrodesis and those treated only by means of fixation without arthrodesis. ${ }^{3}$ 


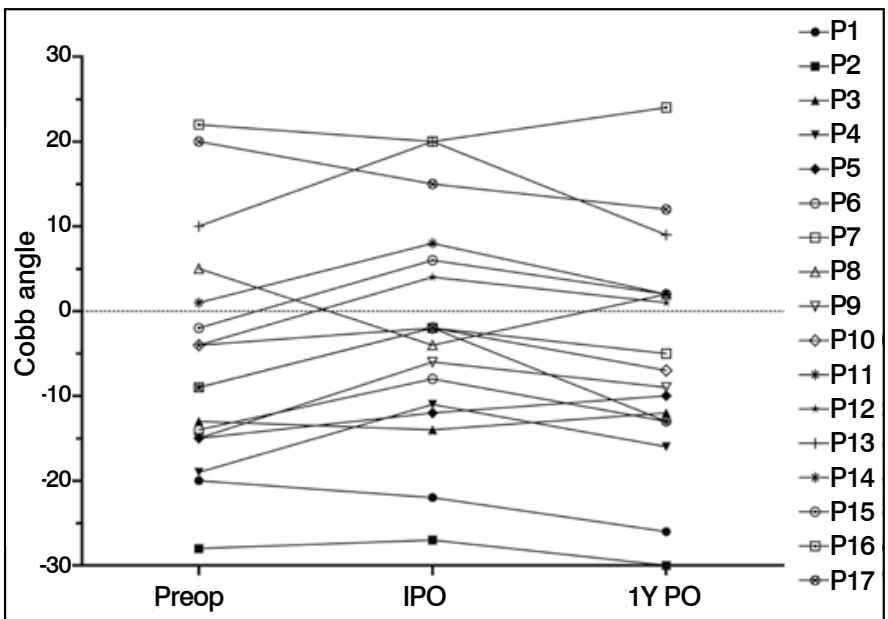

$\mathrm{P}=$ patient; Preop= preoperative measurement; $\mathrm{IPO}=$ immediate postoperative measurement; 1Y $\mathrm{PO}=1$ year after surgery.

Figure 9. Cobb angle measurements in the radiographic evaluations of the patients.

Despite the results described, this study is limited by the fact that the questionnaires were administered only once, during the postoperative period, which does not allow an evaluation of recovery or a comparison with the prior quality of life of the patients. Work-related issues may also be related to some of the outcomes. There is insufficient information in the literature about the application of these questionnaires following fixation using a minimally invasive method, ${ }^{21}$ however, most patients showed satisfactory results, with few physical limitations and little pain.

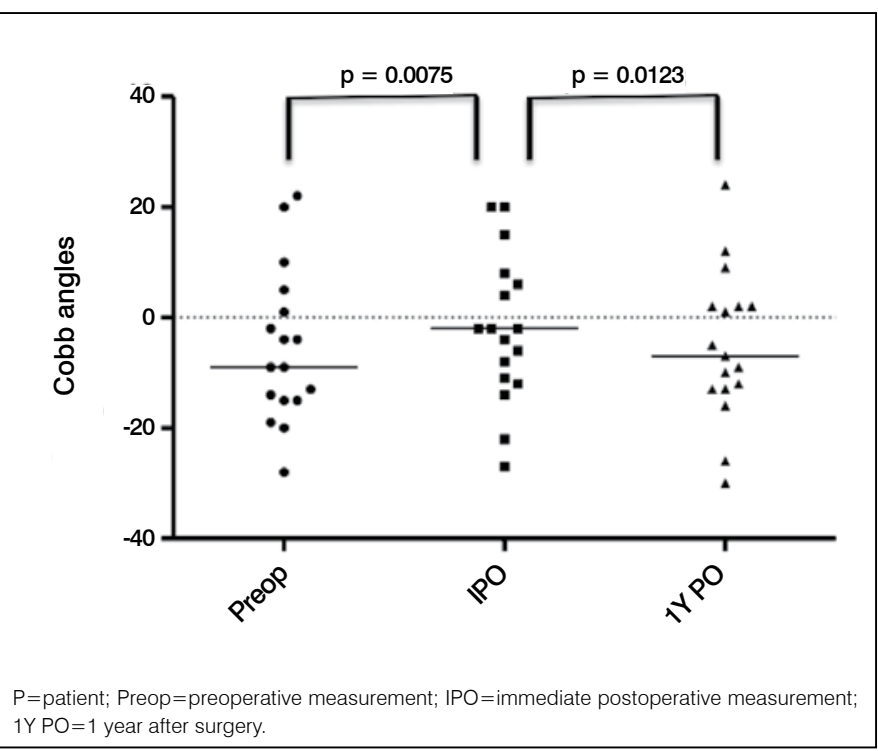

Figure 10. Cobb angle averages in the radiographic evaluations.

\section{CONCLUSION}

The use of minimally invasive percutaneous fixation for the treatment of thoracolumbar spine fractures is a good treatment option and its use for various types of fractures yields satisfactory clinical and radiographic outcomes with low complication rates.

All authors declare no potential conflict of interest concerning this article.

\section{REFERENCES}

1. Aebi M, Etter C, Kehl T, Thalgott J. Stabilization of the lower thoracic and lumbar spine with the internal spinal skeletal fixation system. Indications, techniques, and first results of treatment. Spine (Phila Pa 1976). $1987 ; 12(6): 544-51$.

2. Verlaan JJ, Diekerhof $\mathrm{CH}$, Buskens E, van der Tweel I, Verbout AJ, Dhert WJ, et al. Surgical treatment of traumatic fractures of the thoracic and lumbar spine: a systematic review of the literature on techniques, complications, and outcome. Spine (Phila Pa 1976). 2004;29(7):803-14

3. Wang ST, Ma HL, Liu CL, Yu WK, Chang MC, Chen TH. Is fusion necessary for surgically treated burst fractures of the thoracolumbar and lumbar spine?: a prospective, randomized study. Spine (Phila Pa 1976). 2006;31(23):2646-52.

4. Bailey CS, Dvorak MF, Thomas KC, Boyd MC, Paquett S, Kwon BK, et al. Comparison of thoracolumbosacral orthosis and no orthosis for the treatment of thoracolumbar burst fractures: interim analysis of a multicenter randomized clinical equivalence trial. $\mathrm{J}$ Neurosurg Spine. 2009:11(3):295-303.

5. 5. Wood K, Buttermann G, Mehbod A, GarveyT, Jhanjee R, Sechriest V. Operative compared with nonoperative treatment of a thoracolumbar burst fracture without neurological deficit. A prospective, randomized study. J Bone Joint Surg Am. 2003:85(5):773-81.

6. Logroscino CA, Proietti $L$, Tamburrelli FC. Minimally invasive spine stabilisation with long implants. Eur Spine J. 2009;18(Suppl 1):75-81.

7. Palmisani M Gasbarrini A, Brodano GB, De lure F Cappuccio M, Boriani L, et al. Minimally invasive percutaneous fixation in the treatment of thoracic and lumbar spine fractures. Eur Spine J. 2009;18(Suppl 1):71-4.

8. Barbanti BG, De lure F Cappuccio M, Palmisani M, Boriani L, Gasbarrini A et al. Minimally invasive percutaneous fixation in the treatment of thoracic and lumbar spine fractures. Preliminary experience. GIOT. 2007;33:78-85.

9. Rampersaud YR, Annand N Dekutoski MB. Use of minimally invasive surgical techniques in the management of thoracolumbar trauma: current concepts. Spine (Phila Pa 1976). 2006;31(Suppl 11):S96-102.

10. Marin AG, Herrero CFPS, Nogueira-Barbosa MH, Defino HLA. Fixação percutânea no tratamento de fraturas toracolombares: resultados preliminaries. Coluna/Columna. 2013;12(2):146-8

11. Hartmann F, Gercek E, Leiner L, Rommens PM. Kyphoplasty as an alternative treatment of traumatic thoracolumbar burst fractures Magerl type A3. Injury. 2012;43(4):409-15.

12. Gnanenthiran SR, Adie S, Harris IA. Nonoperative versus operative treatment for thora- columbar burst fractures without neurologic deficit: a meta-analysis. Clin Orthop Relat Res. 2012:470(2):567-77.

13. Gejo R, Kawaguchi Y, Kondoh T, Tabuchi E, Matsui H, Torii K, et al. Magnetic resonance imaging and histologic evidence of postoperative back muscle injury in rats. Spine (Phila Pa 1976). 2000;25(8):941-6

14. Kawaguchi Y, Yabuki S, Styf J, Olmarker K, Rydevik B, Matsui H, et al. Back muscle injury after posterior lumbar spine surgery. Topographic evaluation of intramuscular pressure and blood flow in the porcine back muscle during surgery. Spine (Phila Pa 1976). 1996;21(22):2683-8.

15. KawaguchiY, Matsui $H$, Tsuji $H$. Back muscle injury after posterior lumbar spine surgery. $A$ histologic and enzymatic analysis. Spine (Phila Pa 1976). 1996;21(8):941-4.

16. Kawaguchi $Y$, Matsui $H$, Gejo $R$, Tsuji $H$. Preventive measures of back muscle injury after posterior lumbar spine surgery in rats. Spine (Phila Pa 1976). 1998;23(21):2282-7.

17. Ciconelli RM, Ferraz MB, Santos W, Meinão I, Quaresma MR. Tradução para a lingua portuguesa e validação do questionário genérico de avaliação de qualidade de vida SF-36. Rev Bras Reumatol. 1999:39(3):143-50.

18. Vigatto R, Alexandre NM, Correa Filho HR. Development of a Brazilian Portuguese version of the Oswestry Disability Index: cross-cultural adaptation, reliability, and validity. Spine (Phila Pa 1976). 2007:32(4):481-6.

19. Magerl F, Aebi M, Gertzbein SD, Harms J, Nazarian S. A comprehensive classification of thoracic and lumbar injuries. Eur Spine J. 1994;3(4):184-201.

20. Kuklo TR, Polly DW, Owens BD, Zeidman SM, Chang AS, Klemme WR. Measurement of thoracic and lumbar fracture kyphosis: evaluation of intraobserver, interobserver, and technique variability. Spine (Phila Pa 1976). 2001;26(1):61-5.

21. Wild MH, Glees M, Plieschnegger C, Wenda K. Five-year follow-up examination after purely minimally invasive posterior stabilization of thoracolumbar fractures: a comparison of minimally invasive percutaneously and conventionally open treated patients. Arch Orthop Trauma Surg. 2007;127(5):335-43.

22. Altay M, Ozkurt B, Aktekin CN, Ozturk AM, Dogan O, Tabak AY. Treatment of unstable thoracolumbar junction burst fractures with short- or long-segment posterior fixation in magerl type a fractures. Eur Spine J. 2007;16(8):1145-55.

23. Defino HL, Canto FR. Low thoracic and lumbar burst fractures: radiographic and functional outcomes. Eur Spine J. 2007:16(11):1934-43.

24. Defino HL, Herrero CF, Romeiro CF. Monosegmental fixation for the treatment of fractures of the thoracolumbar spine. Indian J Orthop. 2007;41(4):337-45. 